\title{
THE ANCIENT VERSIONS OF LAMENTATIONS
}

\author{
Herrie F van Rooy \\ Faculty of Theology \\ North-West University
}

\begin{abstract}
The Ancient Versions of the Old Testament can be utilised for different purposes. Two of the most important usages of the Septuagint, Peshitta, Vulgate and the Targums are their use in the process of reconstructing the Hebrew text of the Old Testament and the reception of the Old Testament in different communities. This paper explores the value of the Ancient Versions of Lamentations in these two respects, discussing a representative number of examples. As far as the Hebrew text is concerned, the Ancient Versions were translated from a text close to the Masoretic Text. The Targum and Septuagint shed light on the reception of Lamentations in different Jewish communities, although the Septuagint was transmitted mainly in the Christian community. The Peshitta and Vulgate shed light on the reception in different Christian communities.
\end{abstract}

Key Words: Lamentations, Ancient Versions, Old Testament, Textual Criticism, Septuagint

\section{Introduction}

Any study of the ancient versions of a book in the Old Testament/Hebrew Bible may have one or more of four basic objectives. It could study a text on its own, especially with the aim of reconstructing the original version of the text. That is for example the aim of an eclectic edition of the text of one of the versions, such as the text of the Septuagint published in the Göttingen edition. It could study a version as an aid in reconstructing a text of a book in its Hebrew transmission. In this sense, the ancient versions are important corpora of data to be utilised in critical or diplomatic editions of the Hebrew Old Testament such as the Biblia Hebraica Quinta (a diplomatic edition) or the proposed Oxford Hebrew Bible (an eclectic edition). It could be studied as a primary reading of the Hebrew text as an exercise in reader reception, aiming at understanding the theology or interpretation behind a specific translation, or getting an insight into the aim of that translation. It can also study the translation in the context of its own reception history, which includes the community for which it was translated or the community that accepted that translation as its authoritative document. The two communities should indeed be distinguished, as in the case of the Septuagint, which was translated for a Jewish community but was accepted and transmitted in certain sections of the early church. The aim of this contribution is related to all of the above possibilities, but mainly to two of them, namely the use of the version in reconstructing a Hebrew text and the interpretation underlying the reception of the Hebrew text by the different translators. In the first section of this contribution, a brief survey of the four important translations (the Septuagint, Peshitta, Vulgate and Targum) will be presented. In the following section, a number of examples will be discussed where the versions can help to solve textual problems in the Hebrew Lamentations. The final section will investigate the interpretations underlying some of the receptions of the Hebrew in the 
versions. A paper such as this one cannot be exhaustive, but will focus on representative examples.

\section{The Four Important Ancient versions: Septuagint, Peshitta, Vulgate and Targum(s)}

As far as the Hebrew text of the Book of Lamentations and the four important versions are concerned, a scholarly consensus seems to exist. Consequently, not much new research has recently been done in this regard, with the exception of some major works that state this consensus. When one looks at the two most important surveys of research on Lamentations in the past twenty years, they do not mention problems with regard to the text and the versions as receiving much attention in the past thirty or more years. In his survey of research on Lamentations, Westermann (1990) lists the important works of Albrektson (1963) and Gottlieb (1978). He discusses the work of Albrektson in a brief paragraph (Westermann 1990:39-40), but does not give attention to Albrektson's contribution to the text and versions of the book at all. He does not discuss the work of Gottlieb separately, but only makes a few references to him in his comments on the text of the five songs of Lamentations. It is clear that Westermann does not regard the text and versions of Lamentations problematic enough to warrant much attention.

The same can be said of the survey of Miller (2002). Only one work related to the text and versions is mentioned by Miller, namely the work of Albrektson published in 1963, and that in a survey of work done mainly in the last decade of the previous century. Miller does not give any attention to the text and the versions of Lamentations at all. This state of affairs is confirmed by the treatment of the text and versions of Lamentations in three recent commentaries. Renkema (1998) has no special section dealing with the text and versions, though he treats some issues as part of his commentary. House (2004:281-283) has a brief section on the text of the book, with the latest bibliographical reference to a work on the Targums by PS Alexander from 1986. He affirms the consensus that the four versions were translated from a Hebrew text close to the Masoretic Text (House 2004:281). $\mathrm{He}$ further refers to the view of Albrektson on the Greek and Syriac versions, namely that both are faithful translations of the Hebrew (House 2004:281-282). He also refers to Gottlieb's work (1978), which confirms the view of Albrektson, although it differs in some minor details (House 2004:282). As far as the Aramaic versions are concerned, he refers briefly to the views of Levine and Alexander (House 2004:282-283). Using a long quotation from Levine that states the Targum has rewritten the book, he says the Targum is more than just a translation. Subsequently, he refers to the view of Alexander that from Chapter 3 onwards the Targum presents almost a word for word translation. House bases his discussion of the versions on Albrektson, Gottlieb, Levine and Alexander, and does not mention the Vulgate at all.

Salters (2010) discusses the Hebrew text and the versions of Lamentations more extensively, but does not give much more information than the previous works mentioned. He says that the Hebrew text of Lamentations is in 'a good state of preservation' (Salters 2010:22). He also discusses the fragments of Lamentations from Qumran (Salters 2010:2324). In a few instances, better readings could be found in the Qumran fragments, as well as some agreements with the Septuagint and Peshitta as opposed to the Masoretic Text. His discussion of the Septuagint is based on the edition of Ziegler. The Septuagint of Lamentations is a very literal translation, frequently in inelegant Greek but text-critically very valuable. The minor variants contained in the Septuagint do not presuppose a different Hebrew text (Salters 2010:24). In his discussion of the Peshitta, he links up with the views 
of Albrektson (Salters 2010:24-25). The Peshitta was also translated from a text close to the Hebrew. It is a literal translation, but the translator tried to use good Syriac. In some places, this approach resulted in a freer translation, though restricting the value of the Peshitta for the textual criticism of the Hebrew text. It was translated independently from the Septuagint. Salters's discussion of the Targum is based mainly on the work of Alexander and Van der Heide (Salters 2010:25). He distinguishes between the Yemenite and Western versions. Both traditions show a paraphrasing tendency that is more apparent in Chapters 1 and 2, but not so marked in the final three chapters. About the Vulgate Sanders (2010:26) says that it is a stylish translation that mostly agrees with the consonantal text of the Masoretic Text, but that sometimes the interpretation in the Vulgate differs from the Masoretic vocalisation. Occasionally the Vulgate gives a Christological interpretation in its translation. The remarks of Salters apply to the Vulgate as a whole, not specifically to Lamentations.

It is clear from the remarks above that the views of a few scholars have been accepted to establish a consensus on the Hebrew text as well as on the ancient versions. The important works on the topic are those of Albrektson, Alexander and Van der Heide. Their contributions will therefore be discussed. Ziegler (1957) published the Greek text of Jeremiah and Lamentations in the Göttingen Septuagint and discusses all the important witnesses and text-types, but he does not give detailed attention to translation technique. Neither does he discuss Lamentations on its own, but only as part of his investigation into Jeremiah.

In discussions of the text and versions of Lamentations, the work of Albrektson of 1963 always receives pride of place. His work is of special importance for the Hebrew, Greek and Syriac (Peshitta) versions of Lamentations, especially the latter. He discusses the editions and manuscripts of the Peshitta of Lamentations in its entirety, with a critical text and notes on the text (Albrektson 1963:1-54). It is followed by a detailed discussion of the Hebrew text, the Septuagint and Peshitta, verse for verse through the five chapters of the book (Albrektson 1963:55-207). For this contribution, his summary of the character of the versions is of special relevance (Albrektson 1963:208-213). His views on the Septuagint and Peshitta will be summarised in a number of statements on each. First, the Septuagint:

- The Septuagint is a very literal translation;

- The translator tried to render every Hebrew word in Greek, frequently in a very mechanical way;

- The translator sometimes mistook the Hebrew word for another or had an Aramaic word in mind;

- In some places, the translation would have been unintelligible to a Greek reader;

- There are very few examples of free translations;

- It is not a good translation, but it is valuable for textual criticism on account of the literal character of the translation;

- Its Vorlage is equal to the consonantal Masoretic Text in all essentials;

- The Greek text has been poorly preserved and some deviations from the Masoretic Text may be due to the condition of the text.

The following statements describe the characteristics of the Peshitta of Lamentations:

- It is based on a Hebrew text almost identical to the Masoretic Text;

- It frequently adds 'and' to words and clauses, especially in the middle of a line;

- It contains minor additions, such as pronominal suffixes; 
- Because the translator wanted to make the translation intelligible, some free renderings are found;

- His knowledge of Hebrew was not very good, causing him to guess the meaning of some words and to render some obscure Hebrew words with phonetically similar Syriac words, but with a different meaning from the Hebrew;

- The Peshitta is not dependent on the Septuagint.

Recently Kotzé (2009) reconsidered the literal character of the Septuagint of Lamentations. He refers to the work of Albrektson (Kotzé 2009:78-79), but his aim is a more nuanced description, especially in the light of Van Louw's ideas about the use of dictation in the translation process of the Septuagint (Kotzé 2009:79-81). In his discussion of the issue, he looks closely at two of the criteria proposed by Tov for evaluating the literalness of a translation, namely internal consistency and word order (Kotzé 2009:81-82). Having studied different words that relate to wrongdoing and anger, he concludes that the Greek translator did not render these words consistently (Kotzé 2009:87). Further, he states that word order cannot be used as a criterion on its own in defining literalness (Kotzé 2009:9495). In the light of these findings, he argues for a more nuanced view of the literalness of the Greek Lamentations.

As far as the Peshitta is concerned, the work of Weitzman (1999) tends to support the view of Albrektson. He regards Lamentations as one of the more conservative books in its approach to the translation of the Hebrew (Weitzman 1999:178), with few parallels to the Septuagint (Weitzman 1999:68, 181).

As far as the Targum is concerned, the works of Van der Heide (1981) and Alexander (2007) merit special attention. Van der Heide published a critical text and an exhaustive discussion on the Yemenite tradition of the Targum of Lamentations. This version of the Targum of Lamentations is easily distinguished from the so-called Western tradition (Van der Heide 1981:1). The Western text is longer than the Yemenite one and lacks the vocalisation found in the Yemenite text. The importance of the Western text is enhanced by the fact that no Babylonian version of the Writings has yet been found (Van der Heide 1981:2). Van der Heide regards the Yemenite text as a revised version of the Western text to bring it closer to the Masoretic Text (Van der Heide 1981:35). The work of Van der Heide is still frequently regarded as a starting point for discussing the Targum of Lamentations.

Alexander has done much work on the Targum of Lamentations, reaching a climax with his translation and discussion of this Targum in the Aramaic Bible-series, of which his volume (Alexander 2007) is number 17B. The main part of the volume is dedicated to the Western text, while a translation with notes of the Yemenite text is given in the Appendix. He also regards the Western text as the older one, and refers to the inherent coherence of the Yemenite text (Alexander 2007:2). He further discusses the relationship between the two traditions exhaustively (Alexander 2007:5-11). The differences point to two different editions (or recensions) of the Targum of Lamentations. Alexander's view is that the two traditions stem from the same archetype, that the Western text is closer to the archetype and that the Yemenite text is a recension of the Western text to bring it closer to the Masoretic Text (cf. Alexander 2007:11). Supported by the language of the Targum (Galilean Aramaic), he situates the original translation in the Western region of Palestine, most probably in Galilee, and dates it towards the end of the fifth or the beginning of the sixth century C.E. (cf. Alexander, 2007:87-90). 
Alexander (2007:39) distinguishes two main kinds of translation techniques in Targum Lamentations. The one kind, which he labels Type A, is a very direct, word-for-word translation. This kind of translation is dominant in Lamentations. His Type B is paraphrastic with quite a number of additions to the original. He also distinguishes two subtypes. Type B1 organises the additions as glosses to the base-text, where the additions can be easily separated from the base text, leaving a literal translation. In Type B2, the additions are integrated into the text so that a viable text is not possible when the additions are left out.

Alexander also discusses the possible relation of Targum Lamentations to the other ancient versions. He regards the Septuagint as a very literal translation and says that the translator of the Greek did not have as good a grasp of the Hebrew as the targumist had. There is, however, no clear link between Targum Lamentations and the Septuagint, Aquila or Symmachus (Alexander 2007:46-47). As far as the Peshitta is concerned, Alexander refers to the study of Albrektson. He says that there is no indication that the Peshitta could have used an older form of the Targum, or that Targum Lamentations knew the Peshitta Lamentations. He regards it as a theoretical but improvable possibility that Peshitta Lamentations could go back to an earlier Jewish Targum from north Syria (Alexander 2007:47-48). He discusses the Vulgate of Lamentations as well, but says that there could have been no influence on Jerome from a targumic tradition (Alexander 2007:48-49). There are, however, a number of typical Christian interpretations in the translation. The Hebrew Vorlage was close to the Masoretic Text.

In the light of the preceding discussion, it can be stated that the four ancient versions under discussion all used a Hebrew text very close to the Masoretic tradition as base text. The Septuagint, Peshitta and Vulgate can be regarded as fairly literal translations, each however with its own characteristics. The Targum shows a mixed type, with fairly literal translations as well as paraphrastic and expansive translations.

\section{The Value of the Versions for a Textual Criticism of the Hebrew Text of Lamentations}

The value of the versions for a textual criticism of the Hebrew text of Lamentations could be related to the solution of specific textual problems. The versions can, however, also shed light on the interpretation of unfamiliar words in the text. As far as textual problems are concerned, the question to be answered is whether the version(s) had a different Vorlage than the Masoretic Text. In some instances, a translation can reflect a different vocalisation (interpretation) of a consonantal text, as all the versions were translated from an unvocalised text. In other instances, a version can add something like a conjunction or a possessive pronoun in the process of translation to make the meaning clearer. Frequently, the versions can give no help in matters related to the Hebrew text as such, as some of the differences in a Hebrew text do not reflect in a translation. For the discussion below, the following texts are used:

- Masoretic Text: Biblia Hebraica Stuttgartensia (BHS) (Elliger and Rudolph 1977) and Biblia Hebraica Quinta (BHQ) (Schenker et al. 2004);

- Peshitta: Albrektson (1963);

- Targum: Van der Heide (1981) and Alexander (2007);

- Vulgate: Biblia Sacra XIV;

- 4QLam: Cross (2000). 
An example where a version added a pronoun to the reading of the Masoretic Text can be

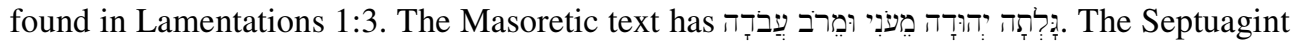

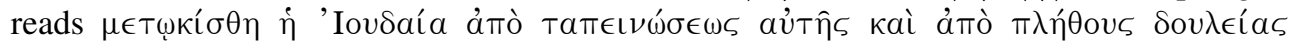

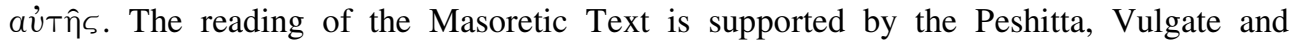
Targum. BHQ regards the addition of the possessive pronouns in the Septuagint as assimilation to the context. Salters (2010:41) mentions two possibilities, one related to the

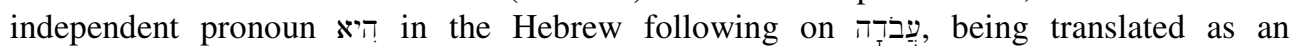
טִבדָדה is read as noun with the third person feminine suffix. The fact that the reading of the Masoretic Text is supported by the other versions makes it evident that the reading of the Septuagint cannot be ascribed to a different Vorlage.

An example where the versions cannot help to decide upon a reading of the Hebrew occurs in Lamentations 2:19, where the word for 'night' appears without the final mater

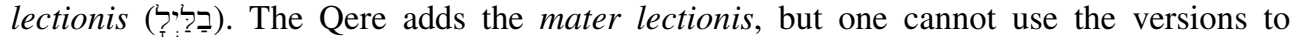
decide this matter, as they all translate the word with the relevant word for 'night' in the different languages.

The first part of Lamentations 1:14 is a good example of variant readings on account of an unknown word and different vocalisation in the interpretation of a text. The Masoretic

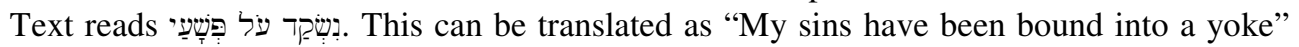
(NIV). The first problem is that the verb at the beginning of the verse is a hapax legomenon, with an uncertain meaning. The translation of the NIV agrees with the solution proposed by Albrektson (1963:73-74), taking the word to have a meaning related to the

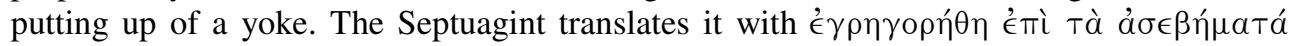
Hov. This is based on two differences from the Masoretic Text. The first one is reading the verb with a 'Shin', not a 'Sin'. However, this would also be a hapax as far as the passive of the verb 'to watch' is concerned ("watch is kept over my sins"). The second change would then be not to read the noun for 'yoke' but the preposition עַשרה 'over'. 4QLam reads, a reading regarded as corrupt by BHQ. Salters (2010:78-79) regards this reading as showing the way to a solution, assuming the reading of the Masoretic Text is caused by metathesis and the confusion of a 'Resh' and a 'Daleth'. The reading of the Septuagint is clearly from the same consonantal text as the Masoretic Text, but with a different interpretation. The readings of the Vulgate and Peshitta also read the same verb as the Septuagint. The Targum probably reads a verb with a 'He' as final radical, as stated by Albrektson (1963:73) and Alexander (2007:120). All these different proposals may be considered, but in the end a final answer is not possible. Perhaps the reading of 4 QLam points in the right direction, while the other witnesses probably had the same consonantal text, but with different interpretations. The only other witness that could have had a different reading in the Hebrew is the Targum.

A very good example, and very well-known, where the versions confirm a compulsory emendation in the Masoretic Text, occurs in Lamentations 4:3. This is a fine example to demonstrate the use of the versions in establishing the text of the Hebrew Lamentations. The Hebrew is as follows: The NIV translates the text as follows: "but my people have become heartless like ostriches in the desert." This translation is the result when the second and third last words are read as one, as proposed by the Qere. This solution is generally accepted, as the reading of the Masoretic text does not make sense.

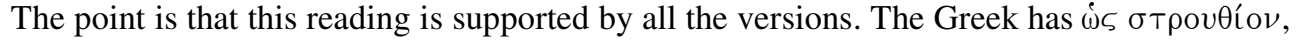
'like a sparrow'. The Vulgate uses the Latin form of the same word (quasi strutio) also in the singular. The Targum has כנעמיא, 'ostriches', while the Peshitta uses the same root in the 
singular. The Masoretic Text has an example of a wrong word division, as shown by all the versions.

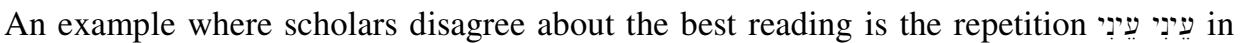
Lamentations 1:16. Some want to retain the repetition and others want to delete the second word. BHS wants to delete one word and BHQ wants to retain the repetition. This example illustrates how difficult it can be to reach a conclusion on account of the readings of the different witnesses. The most important witnesses would be the Masoretic Text itself and 4QLam. These two witnesses disagree, not just with regard to the repetition, but also with regard to the construction of the whole line that contains these words. In the different discussions of this line, the important differences in the constructions in the Masoretic Text and in 4QLam do not receive the necessary attention. The line in the two witnesses is given below:

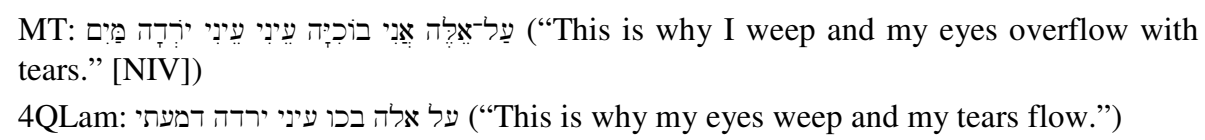

The way in which the line is treated text-critically is exemplified quite well by BHQ. It

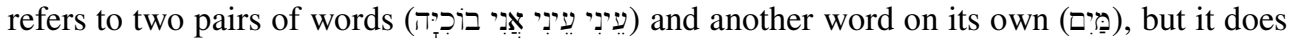
not treat the line as a whole in the apparatus. In its text-critical commentary, BHQ refers to the different syntax of 4QLam, but does not discuss the importance of the different syntactical construction for the line as a whole. In the Masoretic Text, the second verb is regarded as a participle, agreeing with the first verb. In the case of 4QLam, both verbs can be perfects, the first one clearly so and the second one by implication. The two verbs also have different subjects, namely eyes and tear(s). In this instance it would be better to regard the two readings (MT and 4QLam) with their different readings as reflecting two different editions of the book. If this is the case, the reading from Qumran cannot be used to correct the Masoretic Text in this instance. The possibility of a second edition of Lamentations is increased by the variants in Lamentations 1:7 (MT: 'Jerusalem remembered'; 4QLam: 'Remember LORD'). These variants can reflect a different recension or edition as well. In the case of Lamentations 1:16, the versions are then confirming the reading of the Masoretic text as the reading of an edition of the book, followed by the versions.

\section{Translation and Interpretation}

In some of the versions, an introductory paragraph occurs before the translation of Lamentations. Such an introduction sheds light on the specific version's understanding of the context of the book. The introduction had probably already been part of the original

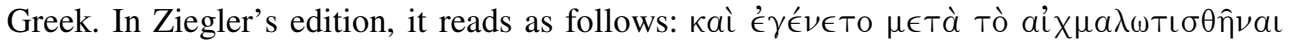

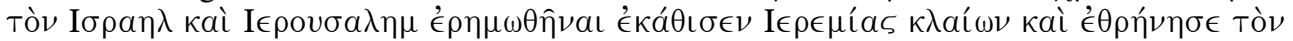

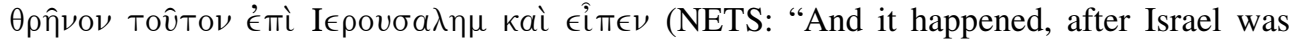
taken captive and Ierousalem was laid waste, Ieremias sat weeping and gave this lament over Ierousalem and said"). A similar introduction appears in the Clementine edition of the Vulgate, as well as in other witnesses. It reads as follows (cf. Biblia Sacra: 285, where variants are listed): et factum est postquam in captiuitatem reductus est isra(h)el et (hi)erusalem deserta est sedit (hi)eremias flens et planxit lamentationem hanc in (hi)erusalem dixit ("and after Israel was led into captivity and Jerusalem was deserted, Jeremiah sat weeping and composed this lament about Jerusalem and said"). The Greek may have been translated from a Hebrew text, but this is not certain (cf. Salters 2010:21). 
Both these introductions state that the book of Lamentations was written by Jeremiah, in line with very old traditions (cf. Salters 2010:4-5). The Peshitta does not have such an

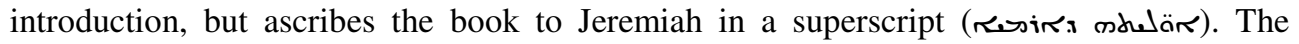
Masoretic text does not have such a superscript.

The Targum of Lamentations does not have a separate introduction. Lamentations 1 is, however, an expanded version. To the first three verses, information is added about the provenance of the book. As discussed above, the Western text of the Targum is probably the older version, with the Yemenite text a shorter one and frequently brought into line with the Masoretic text (cf. Alexander 2007:13-15). This tendency of the Yemenite text can be seen in different places in the introduction. The Western text ascribes Lamentations to Jeremiah (Alexander 2007:109), while the Yemenite text omits the reference (Alexander 2007:188). The Western text has two other references to Jeremiah, in Lamentations 1:2 and 18. In Lamentations 1:1 and 2, Jeremiah is called the high priest. In Lamentations 1:2 the Lord gave a prophecy to Jeremiah in the Western text. The prophecy is mentioned in the Yemenite text, but no mention is made of Jeremiah (cf. Alexander 2007:111 and 188). In both texts, Lamentations 1:18 refers to the lament of Jeremiah. The omission of the name of Jeremiah in Lamentations 1:1 and 2 by the Yemenite text is in agreement with its tendency to bring the Targum closer to the Masoretic Text, emphasising again the dominant position of the Masoretic text in Jewish tradition. On the other hand, the introduction of Moses in both the Targum texts demonstrates the interpretative nature of the Targums. This is especially clear from all the historical references in the Targum. The Masoretic Text has only a few references to other nations (like Sodom, Edom, Egypt and Assyria in Lamentations 4:6, 21 and 22 and 5:6) and is followed in this respect by the other three versions. The Targum has references to the history of the people, to figures like Jeremiah, Josiah, Nebuchadnezzar, Moses, Pharaoh, Titus, Vespasian and Zechariah, the son of Iddo, and to other nations like Ammon, Moab and even the Romans. Understanding Edom as referring to Rome in Lamentations 4:1 agrees with a common rabbinic interpretation (Brady 2003:127). The Targum interpreted Lamentations historically and applied it to events much later than the exile. The introduction of the Targum lays the theological foundation for the rest of the book (Brady 2003:18).

As far as interpretation is concerned, a very interesting example occurs in Lamentations

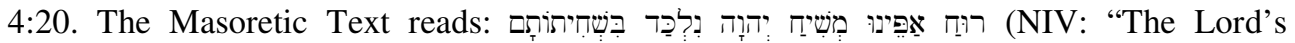
anointed, our very life breath, was caught in their traps.") The important phrase is 'the LORD's anointed'. In the context of Lamentations the phrase refers to the anointed Davidic king, perhaps even to Zedekiah's unsuccessful attempt to escape (Salters 2010:332). The use of the word מְשִ could lead to all kinds of Messianic interpretations. The reading of the Masoretic Text is followed by the Peshitta (riss murs). The critical text of the

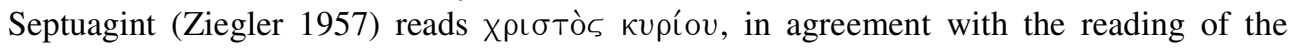
Masoretic Text. This reading, however, does not occur in any of the Greek manuscripts of the Septuagint, only in the Arabic and some Ethiopian manuscripts. The Greek manuscripts all read хрıбтòs кupíos. It was accepted by Ziegler that this was not the original reading of the Septuagint, but the result of a change in the Christian transmission of the Septuagint. The reading of the Vulgate reflects this as well, with the reading christus dominus. Both the traditions of the Targum link the reference to king Josiah, perhaps to diminish the possibility of a Messianic interpretation (cf. Alexander 2007:173-173). The description fits the attempt of Zedekiah to escape, as described in 2 Kings 25:3-7, but the identification with Josiah was probably caused by the targumist's inability to regard Zedekiah as the anointed of God (cf. Brady 2003:42-44). The Messiah is, however, mentioned with regard 
to the punishment of Rome in Targum Lamentations 4:22. This verse is possibly the only instance in Lamentations where a translated text points to a Christian interpretation of an Old Testament text, both in the Vulgate and the Septuagint.

\section{Conclusion}

This paper has explored the value of the ancient versions of Lamentations in solving textcritical problems, as well as the reception of the book by the versions and possible principles underlying the interpretation by the versions. This has been done by studying a representative selection of examples, only scratching the surface of these issues. Much work can still be done, especially with regard to the Lamentation texts from Qumran and their relationship to the Masoretic Text and the versions of Lamentations.

\section{BIBLIOGRAPHY}

Albrektson, B 1963. Studies in the Text and Theology of the Book of Lamentations with a Critical Edition of the Peshitta Text. Studia Theologica Lundensia 21. Lund: CWK Gleerup.

Alexander, PS 2007. The Targum of Lamentations. The Aramaic Bible 17B. Collegeville, Minnesota: Liturgical Press.

Biblia Sacra Iuxta Latinam Vulgatam Versionem 1972. Rome: Typis Polyglottis Vaticanis.

Bradey, CMM 2003. The Rabbinic Targum of Lamentations. Vindicating God. Studies in the Aramaic Interpretation of Scripture 3. Leiden/Boston: Brill.

Cross, FM 2000. 4QLam. In Qumran Cave 4 XI: Psalms to Chronicles, (eds.) E Ulrich et al., 229-237. Discoveries in the Judaean Desert XVI. Oxford: Clarendon Press.

Elliger, K and Rudolph, W 1977. Biblia Hebraica Stuttgartensia. Stuttgart: Deutsche Bibelstiftung.

Gottlieb, H 1978. A Study of the Text of Lamentations. Acta Jutlandica XLVIII. Theology Series 12. Aarhus: Acta Jutlandica.

House, PR 2004. Lamentations. Word Biblical Commentary 23B. Nashville: Nelson.

Kotzé, GR 2009. The Greek Translation of Lamentations: Towards a More Nuanced View of its 'Literal' Character. In Septuagint and Reception. Essays prepared for the Association for the Study of the Septuagint in South Africa, (ed.) J Cook, 77-95. Vetus Testamentum Supplements 127. Leiden/Boston: Brill.

Miller, CW 2002. The Book of Lamentations in Recent Research. Currents in Biblical Research 1(1):9-29.

Renkema, J 1998. Lamentations. Historical Commentary on the Old Testament. Leuven: Peeters.

Salters, RB 2010. Lamentations. International Critical Commentary. London/New York: Clark.

Schenker, A et al. (eds.) 2004. Biblia Hebraica quinta editione cum apparatu critico novis curis elaborato: General Introduction and Megilloth. Stuttgart: Deutsche Bibelgeselschaft.

Van der Heide, A 1981. The Yemenite Tradition of the Targum of Lamentations. Studia Post-Biblica 32. Leiden: Brill. 
Weitzman, MP 1999. The Syriac Version of the Old Testament. An Introduction. Cambridge: University Press.

Westermann, C 1990. Die Klagelieder. Forschungsgeshichte und Auslegung. Neukirchen: Neukirchener Verlag.

Ziegler, J 1957. Septuaginta. Vetus Testamentum Graecum XV: Jeremias, Baruch, Threni, Epistula Jeremiae. Göttingen: Vandenhoeck \& Ruprecht. 